University of Nebraska - Lincoln

DigitalCommons@University of Nebraska - Lincoln

\title{
Characterization of Waste Rock Associated With Acid Drainage at the Penn Mine, California, by Ground-Based Visible to Short-Wave Infrared Reflectance Spectroscopy Assisted by Digital Mapping
}

Irene C. Montero S.

Department of Earth and Planetary Science, University of California, Berkeley, and Earth Resources Center Digital Mapping Laboratory, Berkeley, CA 94720-4767, USA, irenemontero@yahoo.es

George H. Brimhalla

Department of Earth and Planetary Science, University of California, Berkeley, and Earth Resources Center Digital Mapping Laboratory, Berkeley, CA 94720-4767, USA

Charles N. Alpers

U.S. Geological Survey, Placer Hall 6000 J Street, Sacramento, CA 95819-6129, USA

Gregg A. Swayze

U.S. Geological Survey, Mail Stop 964, Box 25046 DFC, Denver, CO 80225, USA

Follow this and additional works at: https://digitalcommons.unl.edu/usgsstaffpub

Part of the Earth Sciences Commons

Montero S., Irene C.; Brimhalla, George H.; Alpers, Charles N.; and Swayze, Gregg A., "Characterization of Waste Rock Associated With Acid Drainage at the Penn Mine, California, by Ground-Based Visible to Short-Wave Infrared Reflectance Spectroscopy Assisted by Digital Mapping" (2005). USGS Staff -Published Research. 344.

https://digitalcommons.unl.edu/usgsstaffpub/344

This Article is brought to you for free and open access by the US Geological Survey at DigitalCommons@University of Nebraska - Lincoln. It has been accepted for inclusion in USGS Staff -- Published Research by an authorized administrator of DigitalCommons@University of Nebraska - Lincoln. 


\title{
Characterization of waste rock associated with acid drainage at the Penn Mine, California, by ground-based visible to short-wave infrared reflectance spectroscopy assisted by digital mapping
}

\author{
Irene C. Montero S. ${ }^{a}{ }^{*}$, George H Brimhall ${ }^{\mathrm{a}}$, Charles N. Alpers ${ }^{\mathrm{b}}$, Gregg A. Swayze \\ ${ }^{\mathrm{a}}$ Department of Earth and Planetary Science, University of California, Berkeley, and Earth Resources Center Digital Mapping Laboratory, \\ Berkeley, CA 94720-4767, USA \\ ${ }^{\mathrm{b}}$ U.S. Geological Survey, Placer Hall 6000 J Street, Sacramento, CA 95819-6129, USA \\ ${ }^{\mathrm{c}}$ U.S. Geological Survey, Mail Stop 964, Box 25046 DFC, Denver, CO 80225, USA
}

Accepted 1 June 2004

\begin{abstract}
Prior to remediation at the abandoned $\mathrm{Cu}-\mathrm{Zn}$ Penn Mine in the Foothills massive sulfide belt of the Sierra Nevada, CA, acid mine drainage (AMD) was created, in part, by the subaerial oxidation of sulfides exposed on several waste piles. To support remediation efforts, a mineralogical study of the waste piles was undertaken by acquiring reflectance spectra (measured in the visible to short-wave infrared range of light $(0.35-2.5 \mu \mathrm{m})$ using a portable, digitally integrated pen tablet PC mapping system with differential global positioning system and laser rangefinder support. Analysis of the spectral data made use of a continuum removal and band-shape comparison method, and of reference spectral libraries of end-member minerals and mineral mixtures. Identification of secondary Fe-bearing minerals focused on band matching in the region between 0.43 and $1.3 \mu \mathrm{m}$. Identification of sheet and other silicates was based on band-shape analysis in the region between 1.9 and $2.4 \mu \mathrm{m}$. Analysis of reflectance spectra of characterized rock samples from the mine helped in gauging the spectral response to particle size and mixtures. The resulting mineral maps delineated a pattern of accumulation of secondary Fe minerals, wherein centers of copiapite and jarosite that formed at low $\mathrm{pH}(<3)$ were surrounded successively by goethite and hematite, which mark progressive increases in $\mathrm{pH}$. This pattern represents the evolution of acid solutions discharged from the pyritic waste piles and the subsequent accumulation of secondary precipitates by hydrolysis reactions. The results highlight the high capacity of the pyritic waste to release further acid mine drainage into the environment, as well as the effectiveness of the mapping method to detect subtle changes in surface mineralogy and to produce maps useful to agencies responsible for remediating the site.
\end{abstract}

(C) 2004 Elsevier B.V. All rights reserved.

Keywords: Reflectance spectroscopy; Acid mine drainage; Jarosite; Copiapite; Goethite; Hematite; Fe sulfates

* Corresponding author. Fax: +1 5106439980

E-mail address: irenemontero@yahoo.es (I.C. Montero S.).

0009-2541/\$ - see front matter (C) 2004 Elsevier B.V. All rights reserved. doi:10.1016/j.chemgeo.2004.06.045

This article is a U.S. government work, and is not subject to copyright in the United States. 


\section{Introduction}

Abandoned mines are one of the most challenging environmental problems faced by government, communities and the mining industry worldwide. The effects of historic mining activity in the western USA are well illustrated in California, where water resources are threatened by the discharge of acid mine drainage (AMD) from a plethora of abandoned mines (California Department of Conservation, 2000). Inadequate characterization of AMD-generating mine wastes is a major obstacle to remediation of their sites. The abundance and variety of abandoned mines is such that a complete inventory and assessment of their environmental impact is far from complete, which hinders the formulation of scientifically and economically sound strategies for remediation.

The purpose of this paper is to present an alternative and efficient way to characterize abandoned mines to assess their potential for AMD discharge. The Penn Mine demonstrates the type of limitations typically encountered in the remediation of AMD-generating sites, such as difficult access to relevant areas due to the steep topography of waste piles, unstable and unknown mine workings, sparse accurate historical records and uncertainty regarding the metal and sulfate load to adjacent water bodies. Uncertainty regarding metal loads can arise from difficulties in detecting and mapping minerals such as water-soluble $\mathrm{Fe}$ sulfates and nanocrystalline $\mathrm{Fe}$ phases. Detection of water-soluble sulfates depends on the amount and timing of precipitation prior to mapping. Mapping of water-soluble sulfates is critical because some of these minerals incorporate considerable amounts of heavy metals that can be quickly released into water bodies after rainfall (Nordstrom and Dagenhart, 1978; Jambor et al., 2000; Takagi and Brimhall, 2001).

Fast and accurate mapping of the mineralogy of waste piles circumvents many of these problems and illustrates the need for efficient characterization methods. Our approach is based on the mapping of minerals that occur on the surface of waste-rock piles and their surroundings, focusing on minerals that serve as indicators of subaerial oxidation of pyrite and the subsequent formation of AMD. In our mapping methods, a digital mapping system is used in combination with a portable reflectance spectrometer that measures reflected solar light in the range extending from visible to short-wave infrared.

Recent years have seen increased interest in the use of remote spectral data to support the characterization and remediation of both operating and abandoned mines (Ferrier, 1999; Swayze et al., 2000; and references therein). At such sites, the combination of geology, mining history and past waste-disposal arrangements often result in geochemical conditions that favor the occurrence of secondary $\mathrm{Fe}$ minerals characteristic of AMD (Alpers et al., 1994a). Minerals such as Fe-bearing sulfates, oxides and oxyhydroxides have chemical and structural properties that make them identifiable by reflectance spectroscopy. Mineral maps based on reflectance spectroscopy can then be used by interdisciplinary teams (Dalton et al., 1998) to identify sources of acidity, to estimate the possible metal load to water bodies from soluble sulfate salts and to aid in the evaluation of the site. The application of spectral data to this problem has been shown to augment considerably the efficiency of the remediation process, saving valuable time and resources (Swayze et al., 2000). At the Penn Mine, Fe mineral maps based on reflectance spectroscopy illustrated the chemical processes taking place in the unsaturated waste dumps and the most active pyrite oxidation "hot spots". Additional potential applications of the mineral maps include, but are not limited to, estimation of the minimum volume of soluble Fe sulfate salts present in the waste piles, estimation of the minimum mass of metals and sulfate likely to be released upon dissolution of soluble $\mathrm{Fe}$ sulfate salts and the prioritization of waste rock piles for removal.

Chemical analysis-based assessment tools such as acid-base accounting, net acid-generation potential and acid-neutralizing capacity have the advantage of providing data regarding the potential reactions, possible secondary minerals and the processes affecting AMD. In comparison with ground-based reflectance spectroscopy integrated into a digital mapping system, such chemical methods have the marked disadvantage of relying on discrete samples that may fail to produce an encompassing view of the minesite, the processes acting in it and where and why critical minerals accumulate.

Ground-based reflectance spectroscopy has been used to aid atmospheric calibration (Kruse and Dwyer, 
1995) of high-altitude remote-sensing data, to provide ground-truthing (Swayze et al., 2000) and as a tool for mineral identification of selected rock outcrops by limited SWIR spectrometers (Hauff et al., 2000). As the technology behind portable spectrometers improves, the combination of spectroscopy with efficient digital mapping allows workers to concentrate on interpreting geochemical processes rather than simply mapping mineral occurrences. Other factors, such as availability of resources (i.e., time, atmospheric conditions and accessibility) highlight the need to make the spectral and spatial links in the field in order to adapt to unforeseen or changing field conditions, enabling the use of the evolving map patterns to delineate effectively the patterns that indicate AMD. The use of portable reflectance spectrometers combined with digital portable mapping systems equipped with differential global positioning system (DGPS) receivers and laser rangefinders facilitates the making of such links by assigning a precise location to each spectral measurement. Additional advantages of ground-based reflectance spectroscopy over high-altitude remote-sensing methods include improved reduction of noise introduced by atmospheric water (due to the short distance between the target and probe and frequent optimization of the instrument with a white reflectance standard) and flexibility regarding coverage and time of acquisition.

\section{Test area: Penn Mine, Calaveras County, CA}

\subsection{History of the Penn Mine}

The Penn Mine is on the shore of Camanche Reservoir (Fig. 1), an East Bay Municipal Utility District (EBMUD) water reservoir on the Mokelumne River. Mining of $\mathrm{Cu}-\mathrm{Zn}$ ore and associated smelting took place at the site from the 1860 s to 1959 , at which point the mine was abandoned (Clark and Lydon, 1962). Reports of fish kills, surface runoff to Camanche Reservoir, elevated metal and $\mathrm{SO}_{4}$ concentrations, and low $\mathrm{pH}$ in groundwater in the vicinity of the mine (Hamlin and Alpers, 1996) prompted efforts for environmental remediation. During 19981999, the mine underwent environmental remediation under the direction of the EBMUD and the California

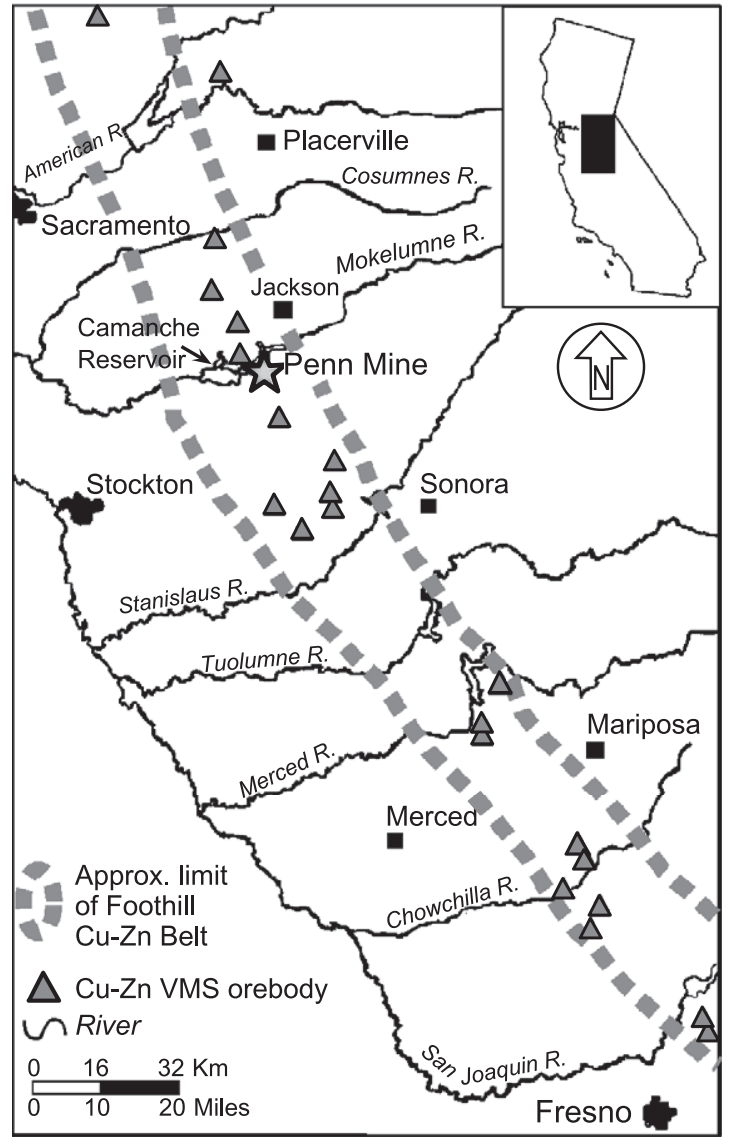

Fig. 1. Location of the Penn Mine site and other $\mathrm{Cu}-\mathrm{Zn}$ VMS deposits within the Sierra Nevada Foothill $\mathrm{Cu}-\mathrm{Zn}$ belt (after Heyl, 1944; Peterson, 1985).

Regional Water Quality Control Board-Central Valley Region.

\subsection{Geological setting}

Mining activity revolved around a volcanogenic massive sulfide (VMS) deposit within the 400-kmlong Sierra Nevada Foothill $\mathrm{Cu}-\mathrm{Zn}$ belt (Fig. 1), created in association with a sequence of submarine sedimentary and volcanic rocks within a Jurassic volcanic island arc (Peterson, 1985, 1988). This VMS deposit, classified as Sierran Kuroko by Singer (1992), was formed by hydrothermal activity in which heated sea water leached metals from existing rocks and formed stratiform lenses of fine-grained sulfides upon expulsion, as black smokers, into anoxic marine 
environments (Singer, 1986). The orebodies and the felsic volcanic rocks that envelop them were subjected to low-grade metamorphism and deformation during accretion to the western edge of North America during the late Jurassic (Martin, 1988). Tertiary quartz gravels unconformably overlie parts of this sequence (Peterson, 1985).

Prior to remediation in 1998-1999 at the Penn Mine, there were $300,000 \mathrm{~m}^{3}$ of solid waste (Davy Environmental, 1993; Hamlin and Alpers, 1996), which included waste rock (low-grade ore and pyritic schist), metallurgical slag, mill tailings, disturbed bedrock and post-mining materials (infrastructure, mechanical aggregates and chemical precipitates). The waste was distributed in at least six wasterock piles, three unlined water impoundments built with waste rock and earthen dams (Fig. 2). For this study, wastes were further classified as acid-producing or not

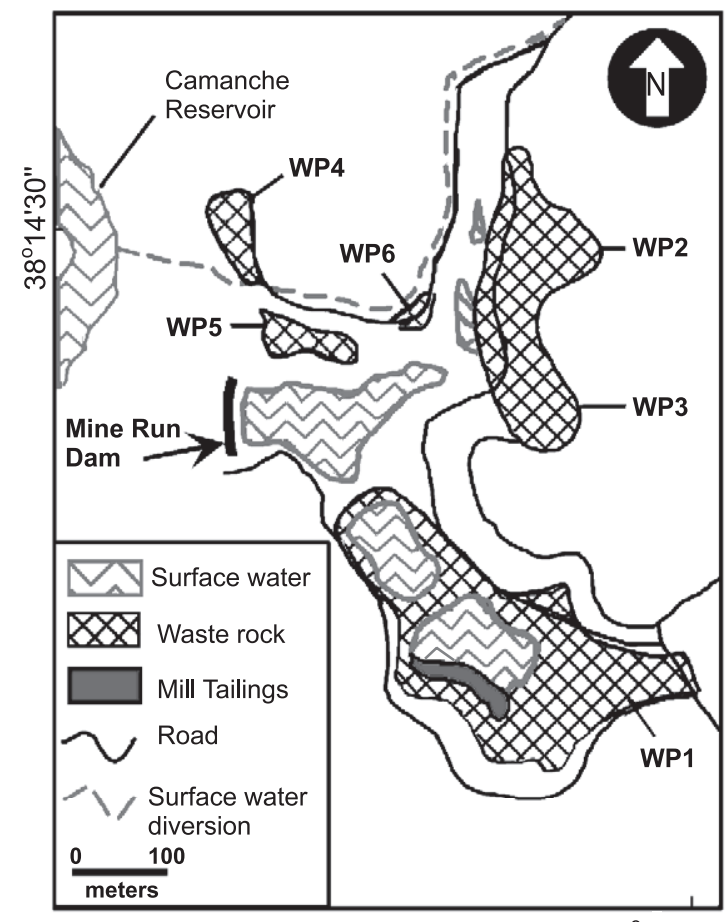

$120^{\circ} 52^{\prime} 30^{\prime \prime}$

Fig. 2. Map of the distribution of waste material and the waste-water impoundments at the Penn Minesite (Davy Environmental, 1993). WP1 through WP6 are waste piles 1 through 6 according to scheme used by Davy Environmental (1993). acid-producing according to their mineral makeup, their relative capability to oxidize and (or) produce acidity in subaerial conditions, and their abundance (Table 1). The pyritic quartz schist host-rock, lowgrade massive sulfide ore, greenschist-grade metavolcanic rock and Tertiary quartz gravel made up most of the material in the waste-rock piles (Table 1). The pyritic schist consisted of quartz-muscovite schist with various degrees of chloritic, sericitic and silicic alteration. The massive sulfide orebodies contained fine-grained pyrite, sphalerite, chalcopyrite and wurtzite, with minor bornite, tetrahedrite and galena, plus barite, calcite and gypsum as gangue minerals (Clark and Lydon, 1962). Low-grade ore consisted of quartzmuscovite schist with pyrite and sphalerite and variable chloritic and sericitic alteration. Greenschist in the waste piles consisted of chloriticized and metamorphosed basalts with abundant quartz and epidote. Prior to remediation, secondary minerals as fine ochreous powders coated many of the rocks in the waste piles and elsewhere on the property. In addition to the minerals listed in Table 1, minor occurrences of secondary fibroferrite $\left[\mathrm{Fe}\left(\mathrm{SO}_{4}\right)(\mathrm{OH}) \cdot 5 \mathrm{H}_{2} \mathrm{O}\right]$, schulenbergite $\left[(\mathrm{Cu}, \mathrm{Zn})_{7}\left(\mathrm{SO}_{4}\right)_{2}(\mathrm{OH})_{10} \cdot 3 \mathrm{H}_{2} \mathrm{O}\right]$ and leonite $\left[\mathrm{K}_{2} \mathrm{Mg}\left(\mathrm{SO}_{4}\right)_{2} \cdot 4 \mathrm{H}_{2} \mathrm{O}\right]$ were detected by powder Xray diffraction in samples from the waste piles. Hamlin and Alpers (1995) reported occurrences of bornite, covellite, brochantite $\left[\mathrm{Cu}_{4}\left(\mathrm{SO}_{4}\right)(\mathrm{OH})_{6}\right]$, halotrichite-pickeringite $\left[(\mathrm{Fe}, \mathrm{Mg}) \mathrm{Al}_{2}\left(\mathrm{SO}_{4}\right)_{4} \cdot 22 \mathrm{H}_{2} \mathrm{O}\right]$ and copiapite $\left[\mathrm{Fe}^{2+} \mathrm{Fe}_{4}^{3+}\left(\mathrm{SO}_{4}\right)_{6}(\mathrm{OH})_{2} \cdot 20 \mathrm{H}_{2} \mathrm{O}\right]$ on the waste piles.

\subsection{AMD and secondary mineralization at the Penn Mine}

Sulfide minerals in the waste piles and in the mine workings were subjected to oxidation in the presence of atmospheric oxygen, microbial communities and aerated meteoric water (Ritchie, 1994). Measurement of how fast this process takes place in situ is complicated by the complex, biologically controlled oxidation pathway and by difficulties relating measured rates to poorly understood physical parameters within a wasterock pile (Nordstrom and Alpers, 1999a). Nonetheless, a general estimate of the rate of pyrite oxidation can be obtained from the laboratory-measured rates of oxidation of pyritic material as measured by flux rates of oxygen depletion. In 
Table 1

Mineralogy of waste-rock piles at the Penn Mine as derived from XRD analysis of representative rock samples

\begin{tabular}{|c|c|c|c|c|c|c|c|c|c|c|c|c|c|c|c|c|c|}
\hline \multirow[b]{2}{*}{ Waste type } & \multirow[b]{2}{*}{ Rock type } & \multicolumn{9}{|c|}{ Primary minerals } & \multicolumn{7}{|c|}{ Secondary minerals } \\
\hline & & $\begin{array}{l}\stackrel{N}{\underline{E}} \\
\stackrel{\Xi}{E}\end{array}$ & 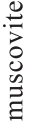 & 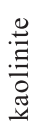 & $\stackrel{.}{\Xi}$ & 营 & : & $\frac{0}{0}$ & $\begin{array}{l}8 \\
\text { ¿े }\end{array}$ & $\begin{array}{l}\hat{3}^{2} \\
\frac{\hat{q}}{\infty}\end{array}$ & 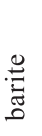 & 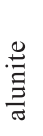 & . & 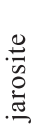 & 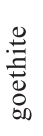 & 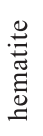 & 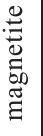 \\
\hline \multirow{2}{*}{$\begin{array}{l}\text { Acid } \\
\text { generating, } \\
\text { natural }\end{array}$} & $\begin{array}{l}\text { Pyritic muscovite- } \\
\text { quartz schist }\end{array}$ & & & & & & & & & & & & & & & & \\
\hline & Massive sulfide & & & & & & & & & & & & & & & & \\
\hline \multirow{2}{*}{$\begin{array}{l}\text { Acid } \\
\text { generating, } \\
\text { mining products }\end{array}$} & $\begin{array}{l}\text { Chemical } \\
\text { precipitate }\end{array}$ & & & & & & & & & & & & & & & & \\
\hline & Mill tailings & & & & & & & & & & & & & & & & \\
\hline \multirow{2}{*}{$\begin{array}{l}\text { Non-acid } \\
\text { generating, post- } \\
\text { mining products }\end{array}$} & $\begin{array}{l}\text { Chemical } \\
\text { precipitate }\end{array}$ & & & & & & & & & & & & & & & & \\
\hline & $\begin{array}{l}\text { Ferruginous mine } \\
\text { waste }\end{array}$ & & & & & & & & & & & & & & & & \\
\hline \multirow{2}{*}{$\begin{array}{l}\text { Non-acid } \\
\text { generating, } \\
\text { natural }\end{array}$} & Greenstone & & & & & & & & & & & & & & & & \\
\hline & $\begin{array}{l}\text { Disturbed } \\
\text { Tertiary gravel }\end{array}$ & & & & & & & & & & & & & & & & \\
\hline
\end{tabular}

Py, cp: pyrite and chalcopyrite. Sp, wz: sphalerite and (or) wurtzite.

laboratory studies in which measurable oxygen was depleted by reaction with pyritic material, oxidation rates ranged from $0.03 \times 10^{-8}$ to $60 \times 10^{-8} \mathrm{~mol} \mathrm{~m}^{-1}$ $\mathrm{s}^{-1}$ (Nordstrom and Alpers, 1999a).

The biologically mediated oxidation process released a low-pH solution, rich in $\mathrm{Fe}^{2+}, \mathrm{Fe}^{3+}$ and $\mathrm{SO}_{4}$, and known as AMD. Before remediation efforts at the Penn Mine, AMD flowed through the unsaturated waste piles and bedrock to unlined water impoundments, reaching the groundwater and ultimately the Camanche Reservoir (Alpers et al., 1994b, 1999). Aluminum, $\mathrm{Cd}, \mathrm{Cu}, \mathrm{Fe}$ and $\mathrm{Zn}$ released by mineral dissolution have been detected in significant amounts in acidic sulfate-rich surface water and groundwater in the area (Hamlin and Alpers, 1996; Alpers et al., 1999).
In waste piles, meteoric water is acidified by the process of sulfide oxidation (mainly microbial oxidation of pyrite) and is then partly neutralized by hydrolysis reactions with aluminosilicates and other minerals present in the waste piles as the solution flows away from active oxidation points. This leads to the accumulation of $\mathrm{Fe}$ sulfates, oxyhydroxides and oxides in a spatial and temporal sequence that represents the buffering of the acidic solution as it moves away from its source (Swayze et al., 2000). Copiapite and jarosite $\left[\mathrm{KFe}_{3}\left(\mathrm{SO}_{4}\right)_{2}(\mathrm{OH})_{6}\right]$ form at $\mathrm{pH}$ values $<3$, and accumulate near sources of acidity that are also sources of heavy metals (Fig. 3; Bigham, 1994; Alpers et al., 1994a; Nordstrom and Alpers, 1999a). Goethite $[\alpha-\mathrm{FeOOH}]$ forms at $\mathrm{pH}$ values generally less than 6 from the dissolution of previous 


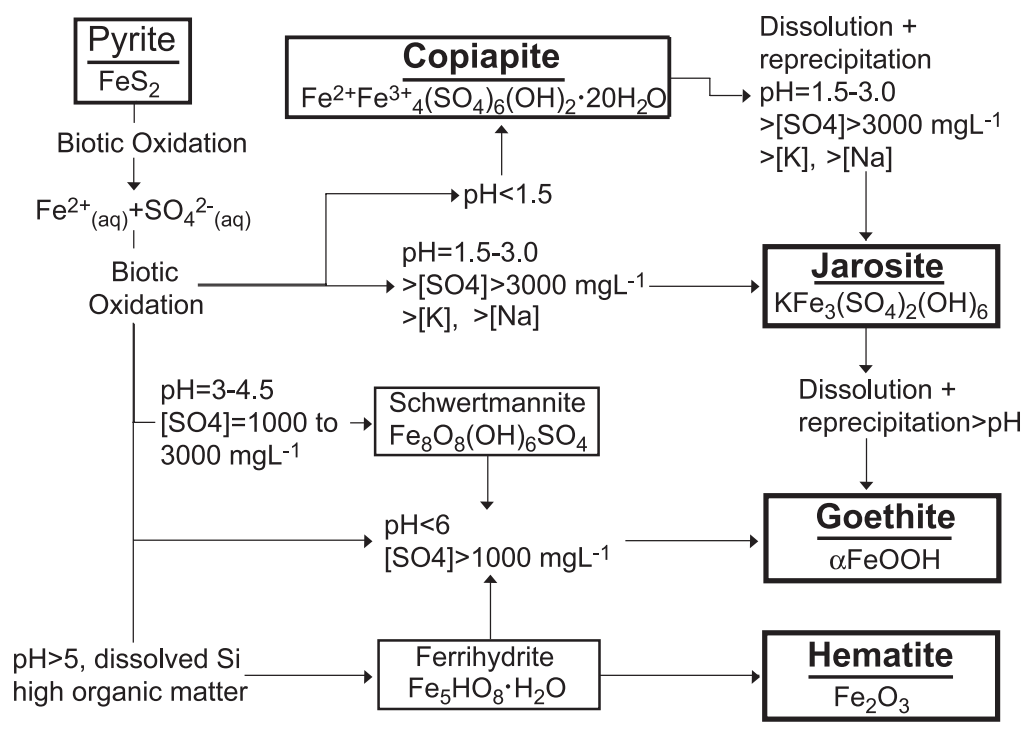

Fig. 3. Model of the accumulation of secondary Fe minerals in Fe sulfide-rich mine-waste environments according to $\mathrm{pH}$ values from field data. Modified from model by Bigham (1994), with additional data from Alpers et al. (1994a) and Nordstrom et al. (1978). Ranges of pH are approximate and are based on field observations of the aforementioned authors. Solid arrows represent possible paragenetic relationships of secondary Fe minerals to sulfide oxidation and to each other. Minerals in bold type were identified on waste-rock piles at the Penn Mine during the course of this study by reflectance spectroscopy.

minerals, including early-formed goethite, and accumulates farther from contaminant sources (Bigham, 1994). Hematite $\left[\mathrm{Fe}_{2} \mathrm{O}_{3}\right]$ accumulates even farther from the sources of acidity after forming in a $\mathrm{pH}$ dependent process that may involve the dehydration and transformation of earlier precipitates, such as those of goethite and ferrihydrite [nominally $\mathrm{Fe}_{5} \mathrm{HO}_{8} \cdot \mathrm{H}_{2} \mathrm{O}$ ], with maximum production occurring at approximately $\mathrm{pH} 8$ (Alpers et al., 1994a). The distribution of these secondary minerals about a source of acidity and active pyrite oxidation forms a spatial pattern in which copiapite and jarosite are relatively abundant near or at the source, and are surrounded by goethite and hematite (Swayze et al., 2000). A pattern of this type affords an opportunity to trace contaminant transport and to identify additional sources of contaminants. Numerous studies (Plumlee et al., 1999) have shown a negative correlation between $\mathrm{pH}$ and the concentration of toxic metals in water draining mines, thus highlighting the importance of mapping lowpH zones.

Water-soluble sulfates, also known as efflorescent sulfate salts (Jambor et al., 2000), are among the most definite indicators of AMD (Nordstrom and Dagen- hart, 1978). These sulfate salts are among the first products of sulfide oxidation and occur above the water table, closest to oxidizing pyrite, and in areas where the exposure of pyrite by erosion and the evaporation of AMD fluids create extremely low $\mathrm{pH}$ values (Jambor et al., 2000). Metals contained in the structure of these minerals (such as $\mathrm{Fe}, \mathrm{Cu}, \mathrm{Zn}, \mathrm{Pb}, \mathrm{Al}$, $\mathrm{Mn}, \mathrm{Mg}$ and $\mathrm{K}$ ) can be readily released upon the rapid dissolution of sulfate salts during rainfall events or increased water flow (Nordstrom and Alpers, 1999b). The presence of efflorescent sulfate salts on surface waste piles depends on precipitation and evaporation rates (Jambor et al., 2000) that affect the $\mathrm{pH}$ and metal content of water in the waste-rock piles. Depending on when and where samples are collected, chemical analyses of water and rock samples can underestimate the extent of soluble sulfate salts. Visual identification of the salts is hampered by their small crystal size and by their similar appearance. Widely used methods such as high-altitude remote sensing commonly do not have the spatial resolution to identify small fields of soluble Fesulfate salts, and unless the methods are applied during different times of the year the seasonality of these salts is missed. 


\section{Instrumentation}

The system (Fig. 4) used to map the mineral distribution of surface material at the Penn Mine incorporates a portable reflectance spectrometer that measures light in the visible, near infrared and shortwave infrared (VNIR/SWIR) range, and a PC pen tablet digital mapping system supported by a differential GPS (DGPS) receiver and laser rangefinder equipped with internal digital inclinometer and magnetic compass.

\subsection{Instrumentation: spectroscopy}

Collection of field reflectance spectra at the Penn Mine, as well as reference spectra of selected mineral samples in controlled laboratory settings, was completed using a commercially available, battery-operated, portable reflectance spectrometer (Fig. 4A). Unlike contact field spectrometers, solar light in the VNIR/SWIR range that is reflected from a target is collected through the end of a fiber-optic cable probe held at a constant distance above the ground throughout the survey (Fig. 4A). Once collected by the probe, light is projected into a diffraction grating, where it is separated by wavelength and reflected onto the unit's three detectors. From 0.35 to $1.05 \mu \mathrm{m}$, a silicon photodiode detector array of 512 channels yields a spectral resolution of $0.003 \mu \mathrm{m}$. From 1.05 to $2.50 \mu \mathrm{m}$, two scanning InGaAs detectors have a resolution of $0.030 \mu \mathrm{m}$ (Analytical Spectral Devices, 1999). Acquisition of spectra takes $100 \mathrm{~ms}$ per spectrum, after which manufacturer-provided software uses the response of the spectrometer to a Spectralon ${ }^{\text {TM }}$ white reflectance standard to convert raw data to reflectance (Analytical Spectral Devices, 1999; use of trade, product or firm names in this publication is for descriptive purposes only and does not imply endorsement by the U.S. government). Collection of the white reference standard must be done frequently during data collection, during optimization of the spectrometer to maintain high signal-to-noise ratios and to compensate for changes in sun angle and for the temporal or spatial variability of atmospheric conditions, such as humidity. The size of a target area on the ground is approximately $30 \mathrm{~cm}^{2}$ if the opening of the fiber-optic cable probe is held at $1 \mathrm{~m}$ above the target.

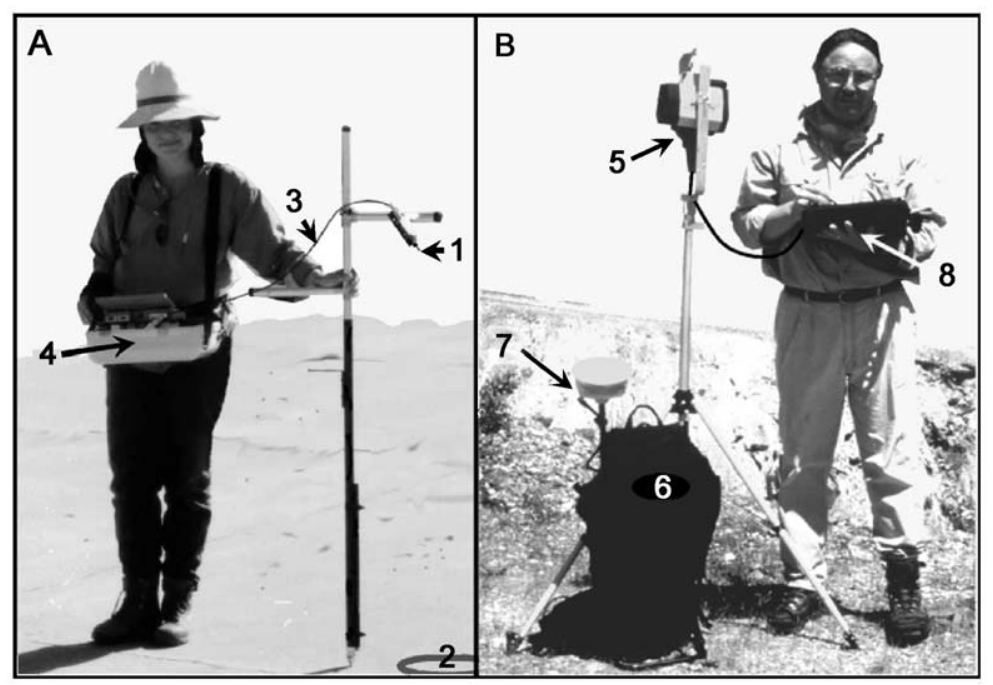

Fig. 4. I. Montero and G. Brimhall demonstrate the use of the digital mapping system. In A: (1) probe holder for the spectrometer's fiber-optic probe. Note that the staff on which the holder rests maintains the probe away from the operator at a constant height and angle above the ground. (2) Target on the ground; (3) fiber-optic cable for transmission of the light from the cable opening to the spectrometer; (4) portable, batteryoperated spectrometer. In B: (5) laser rangefinder with internal digital inclinometer and magnetic compass; (6) portable DPGS receiver, which is inside the backpack; (7) DGPS antenna; (8) pen tablet portable PC computer. 


\subsection{Instrumentation: digital mapping}

The digital mapping system (Fig. 4B) consists of a battery-powered, pen tablet portable computer running a Windows ${ }^{\circledR}$-based surveying-mapping program called Geomapper ${ }^{\circledR}$ (Brimhall and Vanegas, 2001). Location of survey points is supported by a DGPS receiver and a reflectorless laser rangefinder, which link to the PC pen tablet computer via serial ports. A single DGPS receiver uses differential signal correction broadcast by the Omnistar satellite network, which we have measured against known locations to improve the GPS accuracy to approximately $\pm 1 \mathrm{~m}$ horizontally. The location of spectral survey points is determined by a laser rangefinder, which uses an internal compass and inclinometer to compute a vector from a base station (as determined by the DGPS), to the target. The laser rangefinder uses a laser beam with a $3 \mathrm{mrad}$ divergence (Laser Atlanta, 2000) and an internal compass and inclinometer to establish the location of a point away from the base station. Measured independently of the DGPS receiver errors, we determined the precision of the laser rangefinder to be approximately $15.3 \mathrm{~cm}$ up to a distance of $300 \mathrm{~m}$.

\section{Methods}

\subsection{Methods: site survey and sample collection}

Among the several factors that influenced the survey at the Penn Mine were the nature of the surface materials, the topography of the site and the risks associated with an abandoned minesite. Remediation of the waste materials by several regional and local agencies was to take place almost immediately after the completion of the survey, thus limiting the amount of time available. Furthermore, frequent rainstorms resulting from the 1998 'El Niño' event proved to be the most limiting factor during the spectral survey. All spectra reported in this work were acquired after a 2-week dry period, during 2 lowhumidity days in late May 1998.

Accessible areas on five wasterock piles were mapped with spectral measurements regularly spaced at 5-m intervals. Six remote measurements, spaced at $10-\mathrm{m}$ intervals, were acquired on otherwise inacces- sible steeper western slopes of WP2 and WP3 (Fig. 2) from a distance of $5 \mathrm{~m}$ using a long-distance foreoptic attachment that directed light within an $18^{\circ}$ solid angle to the spectrometer's probe. The use of longdistance foreoptic attachments has the advantage of providing meaningful reflectance spectra from distances of up to $100 \mathrm{~m}$, thus increasing the efficiency of the method to map inaccessible areas of abandoned mines. Areas of interest and sampling geometry were defined on the basis of previous knowledge about the site (Davy Environmental, 1993; Hamlin and Alpers, 1996) and on insight gained through visual inspection of the field spectra during acquisition. The grid spacing was selected on the basis of the size of the area and available time. Control points were established with DGPS along the length of waste piles and were checked with a surveying tape. From control points, a mapping operator used the laser rangefinder to locate the position of a second moving spectrometer operator. Care was taken to collect spectra over dry material during the hours from 10 a.m. to 3 p.m., when the sun was at less than $40^{\circ}$ from its zenith, to maintain a high signal-to-noise ratio. During surveying, the probe of the spectrometer was held at a height of approximate $1 \mathrm{~m}$ above the ground at $90^{\circ}$ from horizontal, with care to keep shadows or reflective material away from the ground target.

Sixty spectral measurements were averaged for each spectrum. Spectra acquisition and logging of spectra location and identification number in the pen computer required, on average, 1 min per spectrum. This included time for spectral corrections (darkcurrent correction, optimization of the spectrometers and acquisition of a white reference) completed at a rate of one every third spectrum. In total, two operators acquired and surveyed 513 field spectra over five waste piles covering a total area of approximately $25,000 \mathrm{~m}^{2}$ in $<12 \mathrm{~h}$ ( 2 days) accurately surveyed fieldspectra locations and other features of the site. Twentyfour samples of waste rock were collected and saved in polypropylene bags as the survey progressed by scraping the top $2-3 \mathrm{~cm}$ of surface material in areas previously measured by the spectrometer.

\subsection{Rock-sample analysis}

Post-processing involved the conversion of the field spectra to ASCII format and uploading of data to 
a computer workstation for mineral identification. Location and logistic information regarding both the field spectra and other features were exported into a geographical information system (GIS) database of the Penn Mine. After surveying was completed, each waste-rock sample was carefully oriented, put into a dark box illuminated with two quartz-halogen lights, and its reflectance spectrum relative to that of a Spectralon ${ }^{\circledR}$ standard was measured with the same spectrometer used during fieldwork. The different materials observed in each waste rock sample were then visually separated into subsamples (greenstone, pyritic schist or precipitate), ground with an agate mortar and pestle, and analyzed by powder X-ray diffraction (XRD) using a $\mathrm{Cu}$ X-ray source. The surfaces of 22 rock samples were analyzed separately by scratching the top $0.5-1 \mathrm{~mm}$ with a stainless steel tool and analyzing by XRD. The study of the top 1 $\mathrm{mm}$ of each rock sample was crucial for understanding the influence of substrate materials on the reflectance spectrum. Additional XRD study was conducted for 22 rock samples, for which $3 \mathrm{~g}$ portions were finely ground, suspended in distilled water and gravity-settled onto glass slides to improve detection of the sheet silicates (hereupon referred to as settling XRD). The XRD scans were obtained with a step of $0.01^{\circ} 2 \theta$, at a scan rate of 2-3 s per step, depending on the need to minimize X-ray fluorescence from $\mathrm{Fe}-$ rich minerals. Identification of minerals from the XRD spectra was completed using commercial matching programs. Although care was taken to check for them, poorly crystallized nanophase Fe minerals such as ferrihydrite and schwertmannite were not identified in the samples analyzed. Hydrous $\mathrm{Fe}$ sulfates such as melanterite or rozenite were also not identified in the samples analyzed. Previous studies of the Penn Mine by Hamlin and Alpers (1995) also failed to detect melanterite or rozenite on the waste piles. Quartz, albite, muscovite, clinochlore, clinozoisite and epidote were detected as the main primary silicates in the waste piles. Jarosite, goethite and hematite were the main secondary Fe minerals, occurring as coatings on larger rock fragments, as very fine loose grains and as aggregates over pyritic waste piles. Hematite was the only secondary $\mathrm{Fe}$ mineral in greenstone samples. Muscovite and chlorite were the most abundant sheet silicates, and even after settling XRD, illite was observed in only two samples of waste-pile material. Kaolinite was detected in only two samples, and siderophyllite and glauconite each were detected in one greenstone sample. Pyrite, sphalerite, wurtzite and chalcopyrite were the only sulfides detected in low-grade ore and pyritic schist. Quartz and albite were the most abundant minerals in both pyritic schist and greenstones. The XRD study indicated that most of the finer particles consisted of muscovite, chlorite and secondary Fe minerals. Finegrained barite and alunite were found in mill tailings that were not spectrally surveyed.

\subsection{Basis for spectral interpretation and mineral identification}

Field reflectance spectra of rocks measured over the VNIR/SWIR range represent the selective absorption of sunlight by electrical and vibrational processes within a mineral's structure (Gaffey et al., 1993). The spectra can be used to resolve chemical composition and crystal structure, and to determine purity.

Electrical processes involving orbital electrons in transition metals give rise to broad absorption features that are observed from 0.4 to $1.3 \mu \mathrm{m}$ (electrical region, Fig. 5A). Reflectance spectra of Fe minerals reflect single- and paired-electron transitions between energy levels in unfilled $3 d$ orbitals and metal-ligand electron transfers (Sherman and Waite, 1985). The wavelength and intensity of absorption features in this region depend on the nature of the crystal field around the Fe atom and on the nature of the bonds around it because the nature of magnetic coupling between $\mathrm{Fe}^{3+}$ ions (as influenced by the crystal field) facilitates the transition of electrons between energy states (Townsend, 1987; Sherman and Waite, 1985; Rossman, 1976). Thus, in $\mathrm{Fe}^{3+}$ minerals, subtle differences in the shape and wavelength of the absorption features detectable after continuum removal reflect the crystal structure of the minerals and allow for their identification. Hematite possesses a structure of closely packed face-sharing $\mathrm{FeO}_{6}$ octahedra (Burns, 1993), and the strong antiferromagnetic interactions among the $\mathrm{Fe}^{3+}$ ions affect the electron transitions and electric charge transfers to create a very strong absorption (delineated by low reflectance) at wavelengths shorter than 0.55 $\mu \mathrm{m}$ (Rossman, 1996; Fig. 5A). A strong absorption caused by $\mathrm{Fe}^{3+}$ electron transition is characteristic at $0.85-0.9 \mu \mathrm{m}$, with a concave downward inflection at 

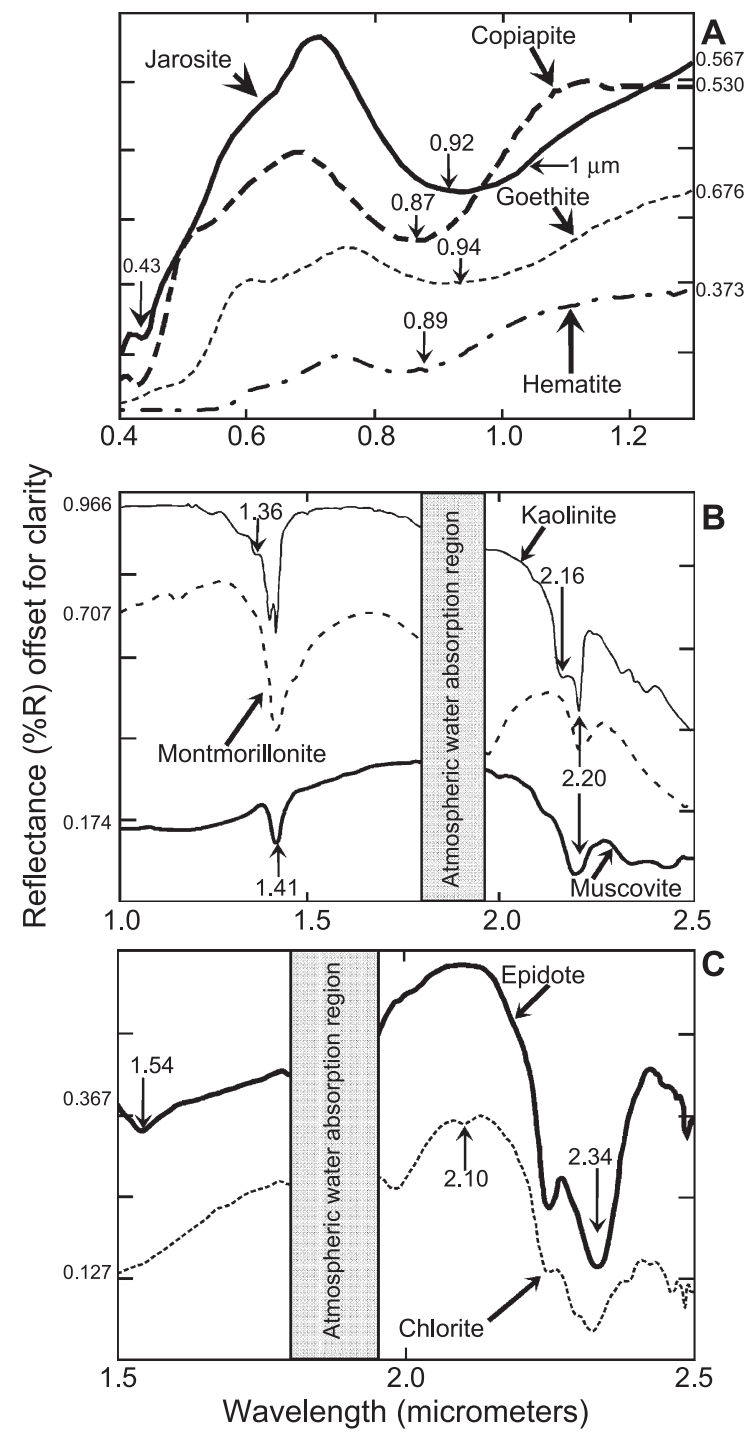

Fig. 5. Laboratory reflectance spectra of selected reference minerals. Spectra are offset vertically for clarity. Bold arrows identify mineral spectra. Light arrows indicate absorption features used in the identification of spectra, and the center of that feature (in $\mu \mathrm{m}$ ) obtained by the continuum removal method of Clark et al. (1990a). (A) Secondary Fe minerals; horizontal arrow at $1.0-\mu \mathrm{m}$ notes inflection point of jarosite. (B) Kaolinite, montmorillonite and muscovite. (C) Epidote and chlorite.

0.9-0.95 $\mu \mathrm{m}$ (Fig. 5A; Morris et al., 1985). The ferrihydrite structure has similarities to that of hematite except that some of the Fe sites are vacant and some oxygen sites are taken by $\mathrm{H}_{2} \mathrm{O}$ and $\mathrm{OH}^{-}$

(Murray, 1979). Electron and paired-electron transitions in $\mathrm{Fe}^{3+}$ cause a strong absorption centered at approximately $0.50 \mu \mathrm{m}$ and a broad absorption at wavelengths greater than $0.95 \mu \mathrm{m}$, respectively (Bishop and Murad, 1996). Goethite has edge-sharing $\mathrm{FeO}_{6}$ octahedra; paired and single $\mathrm{Fe}^{3+}$ electron transitions (Sherman et al., 1982) cause a strong absorption at $0.45 \mu \mathrm{m}$ (edge at $0.55 \mu \mathrm{m}$ ) and a broad asymmetric absorption between 0.90 and $1.00 \mu \mathrm{m}$ (Morris et al., 1985; Hunt et al., 1971). In schwertmannite $\left[\mathrm{Fe}_{8} \mathrm{O}_{8}(\mathrm{OH})_{6} \mathrm{SO}_{4}\right]$, the presence of $\mathrm{SO}_{4}^{2-}$ bridges between some edge-sharing $\mathrm{FeO}_{3}(\mathrm{OH})_{3}$ octahedra creates two sites for $\mathrm{Fe}^{3+}$ (Bigham et al., 1990), which are reflected in a very broad asymmetric absorption feature at $0.9 \mu \mathrm{m}$ and a strong absorption with a steep edge at wavelenghts less than $0.5 \mu \mathrm{m}$ (Bishop and Murad, 1996). Jarosite has edge-sharing $\mathrm{FeO}_{6}$ octahedra bridged by hydroxyl and sulfate groups that form sheets separated by $\mathrm{K}^{+}$ions (Rossman, 1976). Bridging of $\mathrm{Fe}$ by both $\mathrm{OH}^{-}$and $\mathrm{SO}_{4}^{2-}$ gives rise to four electron and paired-electron transitions noted in the spectrum of well-crystallized jarosite (Fig. 5A; Morris et al., 1996). Spectral features diagnostic of jarosite include a narrow absorption feature near $0.43 \mu \mathrm{m}$ and a broad feature near $0.92 \mu \mathrm{m}$. An inflection past $1.0 \mu \mathrm{m}$ affects the symmetry of the broad absorption feature (Fig. 5A). In copiapite, $\mathrm{Fe}^{3+}$ octahedra are linked by corner-sharing $\mathrm{OH}^{-}$and $\mathrm{SO}_{4}$ molecules to form chains, and $\mathrm{Fe}^{2+}$ occupies the center of an isolated and weakly connected $\mathrm{Fe}\left(\mathrm{H}_{2} \mathrm{O}\right)_{6}$ octahedron at the origin of the unit cell (Fanfani et al., 1973). The strong magnetic interaction of ferric ions through the hydroxyl bridge gives rise to intense, narrow and symmetric absorption features at approximately 0.43 and $0.87 \mu \mathrm{m}$ (Rossman, 1975). Other Fe-bearing silicates (such as olivine, pyroxene and Fe-bearing smectites) that absorb in this range are not discussed because these minerals were not observed in this study and have not been reported to occur in rocks of the Penn Mine.

Combinations and overtones of fundamental vibrational modes of molecules such as $\mathrm{H}_{2} \mathrm{O}, \mathrm{CO}_{3}^{2-}$ and $\mathrm{OH}^{-}$in mineral structures produce absorption features that can be observed most prominently in the vibrational region of the spectrum from 1.3 to $2.5 \mu \mathrm{m}$ (Clark et al., 1990c). Kaolinite, muscovite and illite display combinations of an $\mathrm{Al}-\mathrm{OH}$ bend overtone and an $\mathrm{OH}$ stretch (Fig. 5B; Clark et al., 1990c) that arise within 
an edge-sharing $\mathrm{Al}(\mathrm{OH})_{6}$ octahedral layer (gibbsite layer) linked to sheets of $\mathrm{SiO}_{4}$ tetrahedra (Klein and Hurlbut, 1993). In kaolinite $\left[\mathrm{Al}_{2} \mathrm{Si}_{2} \mathrm{O}_{5}(\mathrm{OH})_{4}\right]$, the gibbsite layer is linked via corner oxygens to one sheet of $\mathrm{SiO}_{4}$ tetrahedra (Klein and Hurlbut, 1993), which affects the vibration of the Al- $\mathrm{OH}$ molecule to create a double feature at 2.16 and $2.2 \mu \mathrm{m} ; \mathrm{OH}$ vibration stretch overtones create another doublet near $1.4 \mu \mathrm{m}$ (Fig. 5B; Clark et al., 1990c). Muscovite $\left[\mathrm{KAl}_{2}\left(\mathrm{AlSi}_{3}\right) \mathrm{O}_{10}(\mathrm{OH})_{2}\right]$ has two $\mathrm{SiO}_{4}$ layers linked via corner oxygens to the gibbsite layer, as well as some $\mathrm{Al}$ substitution for $\mathrm{Si}$ in tetrahedral sheets, and has characteristic narrow features at 1.4 (due to an overtone of an $\mathrm{OH}$ stretch), 2.2 and $2.34 \mu \mathrm{m}$ (due to an Al$\mathrm{OH}$ bend vibration mode; Clark et al., 1990c). Although illite $\left.\left[\left(\mathrm{K}_{0.65} \mathrm{Al}_{2.0}\right) \sim \mathrm{Al}_{0.65} \mathrm{Si}_{3.35} \mathrm{O}_{10}(\mathrm{OH})^{2}\right]\right]$ departs from the composition of muscovite (Klein and Hurlbut, 1993) both have similar features at 2.2, 2.34 (due to $\mathrm{Al}-\mathrm{OH}$ bend mode) and near $1.4 \mu \mathrm{m}$ (due to an overtone of a OH stretch; Hunt, 1979; Gaffey et al., 1993). Montmorillonite $\left[(\mathrm{Na}, \mathrm{Ca})_{0.3}(\mathrm{Al}, \mathrm{Mg})_{2}\right.$ $\mathrm{Si}_{4} \mathrm{O}_{10}(\mathrm{OH})_{2} \cdot n \mathrm{H}_{2} \mathrm{O}$ ] displays an $\mathrm{Al}-\mathrm{OH}$ bend feature near $2.2 \mu \mathrm{m}$ (Fig. 5B), and overtones of $\mathrm{OH}$ vibrational modes and combinations of $\mathrm{H}_{2} \mathrm{O}$ vibrational modes create a broad features near 1.41 and $1.9 \mu \mathrm{m}$ respectively (Bishop et al., 1994). Distinction among these minerals requires high resolution and appropriate shape analysis because differences in shape arise from structural differences concerning the Al site (Hunt, 1979); careful analysis is needed particularly for the smectite clays, wherein substitution of cations such as $\mathrm{Fe}$ and $\mathrm{Mg}$ for octahedral $\mathrm{Al}$ can alter the shape of the $2.2 \mu \mathrm{m}$ absorption and other features related to modes of the $\mathrm{H}_{2} \mathrm{O}$ molecule (Clark et al., 1990c; Bishop et al., 1994). Iron-bearing silicates such as epidote $\left[\mathrm{Ca}_{2}\left(\mathrm{Fe}^{3+}, \mathrm{Al}\right)_{3}\left(\mathrm{SiO}_{4}\right)_{3}(\mathrm{OH})\right]$ and chlorite (Fig. 5C) can show electrical features (chlorite can show $\mathrm{Fe}$ transitions near $0.4,0.7,0.9$ and $1.0 \mu \mathrm{m}$ ), but were most reliably identified on the basis of their vibrational features. Chlorite $\left[(\mathrm{Mg}, \mathrm{Fe})_{5} \mathrm{Al}\left(\mathrm{Si}_{3} \mathrm{Al}\right) \mathrm{O}_{10}(\mathrm{OH})_{8}\right]$ displays a complex multiple band between 2.1 and $2.3 \mu \mathrm{m}$ that is interpreted to result from combined $\mathrm{OH}$ stretching modes and $\mathrm{Mg}-\mathrm{OH}$ bend modes (Hunt, 1979; King and Clark, 1989). Epidote shows a double absorption near $2.3 \mu \mathrm{m}$, possibly resulting from $\mathrm{Fe}-$ $\mathrm{OH}$ bend and $\mathrm{OH}$ stretching modes (Clark, 1999); an additional feature at $1.54-1.55 \mu \mathrm{m}$ arises from an $\mathrm{OH}$ combination stretch mode as observed in clinozoisite
$\left[\mathrm{Ca}_{2} \mathrm{Al}_{3}\left(\mathrm{SiO}_{4}\right)_{3}(\mathrm{OH})\right]$ and epidote by Hunt et al. (1973), and also in greenstones at the Penn Mine. Quartz and most feldspars, including albite, lack molecules that produce vibrational or electrical features over the spectral range of interest, although they can show $\mathrm{H}_{2} \mathrm{O}$-related features around 1.4 and $1.9 \mu \mathrm{m}$. Other parameters, such as particle size, particle orientation, particle shape, packing, porosity, type of surface and viewing angle also affect the albedo and the relative intensity of absorption features, or spectral contrast, to an extent determined by the optical properties of the material (Adams and Filice, 1967). However, because the presence and position of absorption features after continuum removal are affected to a lesser extent, identification is possible (Gaffey et al., 1993; Clark and Roush, 1984; Clark, 1999). The use of sets of continuum-removed absorption features, in addition to knowledge of the effects of mixing and of variation of particle size in mixtures (acquired from spectral analysis of well-known samples), helped reduce the uncertainty in assigning spectral absorption features to the mineral occurrences.

Identification of minerals from field spectra was carried out using the apparent continuum removal and Band Shape Least-Squares algorithm developed by Clark et al. (1990a,b). This algorithm identifies minerals by matching the unknown spectrum to those of reference minerals by removing from both an apparent continuum (alternatively described as background reflectance) and using a modified least-squares routine to compare their continuum-removed shapes over a defined wavelength range. The result of the comparison is a fit value. The fit value, if satisfactory (i.e., above a threshold), is compared to fit values obtained from comparison with several other mineral reference spectra, and the best spectral match is selected. Note that, in the context of this work, the apparent continuum removal and algorithm of Clark et al. (1990a) were used to identify the spectrally dominant mineral in the field spectra by comparing selected continuum-removed absorption bands to those in a reference library of continuum-removed spectra over the same spectral range. Unmixing and correlation of spectral depth to mineral abundance were not attempted because of the nature of intimate mixtures of mineral grains on the surface of the waste piles. Instead, a digital spectral library tailored to the Penn Mine, which contained more than 100 reference 
spectra of pure minerals, and more than 30 mechanical binary mixtures of pure minerals and naturally occurring mixtures, was used for the band-shape comparison. The library data were acquired with the same instrument that was used for fieldwork and also incorporated spectra from the U.S. Geological Survey. Reference minerals were obtained from the Mineral Museum at the University of California-Berkeley, the mineral collection of the Smithsonian Department of Mineral Sciences and from the Penn Mine, and were characterized by XRD, sieving and visual examination. One set of reference spectra was acquired using solar light under atmospheric conditions and geometry similar to those encountered during the spectral survey of the Penn Mine, and a second set was acquired in a dark box illuminated with two quartz-halogen lights. A large reference library with many different types of samples of various grain sizes, packing, degrees of purity and extent of mixing, is crucial for the spectral identification of minerals because of the effect of these physical parameters on the spectra.

The study of laboratory spectra of characterized rock samples and of reference minerals was completed prior to the interpretation of field spectra. The analysis of the reflectance spectra of the 'standards' provided the wavelength ranges most diagnostic of each mineral of interest for application of the apparent continuum removal algorithm. Identification of secondary $\mathrm{Fe}$ minerals was focused on the comparison between the field spectra and reference spectra in the range from 0.75 to $1.3 \mu \mathrm{m}$. Identification of sheet silicates and $\mathrm{Mg}-\mathrm{Fe}$-bearing silicates was done mainly by identification of sets of absorption features after continuum removal in the range from 1.9 to 2.4 $\mu \mathrm{m}$. Despite jarosite having characteristic features in the vibrational region, in natural mixtures with muscovite or kaolinite the features of jarosite and goethite were observed to be masked in the 1.9-2.4$\mu \mathrm{m}$ region by the more spectrally dominant features of the sheet silicates. Many $\mathrm{Fe}$ minerals are weak absorbers in the 1.3-2.2- $\mu \mathrm{m}$ region; if present as submicrometer coatings on a substrate that is a strong absorber in the 1.3-2.2- $\mu \mathrm{m}$ region, the spectra of the substrate dominates (Sherman et al., 1982). This type of association illustrates the difficulty in identifying minerals from the spectra of geological materials, many of which are intimate mixtures of fine-grained to amorphous minerals. Reflectance spectra of mix- tures are a nonlinear expression of the combined spectra of the pure mineral end-members and their abundances, in a way that reflects the accessibility of light to each mineral grain, the complexity of intergrain and intragrain light reflection and scattering, and the optical properties of each type of mineral grain (Adams and Filice, 1967). In the study of secondary minerals, variations in grain size that affect the relative intensities of overlapping absorption features must be considered because small secondary minerals commonly coat larger particles and dominate the reflectance spectra (Gaffey et al., 1993).

\section{Results and discussion}

\subsection{Interpretation of reflectance spectra}

Secondary $\mathrm{Fe}$ minerals in rock samples were identified, using the apparent continuum removal and band-shape least-squares algorithm, on the basis of the diagnostic $\mathrm{Fe}^{3+}$ absorption in the electrical part of the spectrum from 0.4 to $1.3 \mu \mathrm{m}$. Absorption edges and peaks were not used in the identification process. The secondary Fe minerals occur as fine-grained powdery coatings or as a thin laminate on oxidized pyritic schist. When powdery coatings of jarosite were identified by $\mathrm{XRD}$, confirmation by spectroscopy was unambiguous. For jarosite coatings too thin to be detected by $\mathrm{XRD}$, the spectra displayed typical features of jarosite at 0.43 and $0.92 \mu \mathrm{m}$ after continuum removal (Fig. 6A). Quartz-muscovite pyritic schist in which secondary Fe minerals represented a minimal fraction on the surface typically yielded high albedo and relatively flat reflectance spectra with poorly defined features in the electrical region (Fig. 6B). Samples of rock chips consisting of various proportions of pyritic schist, greenstone, gravel and ferruginous precipitate typically contained a mixture of jarosite and goethite, with only jarosite unambiguously detected by XRD. Analysis of these complicated spectra (Fig. 6C) identified only the most spectrally dominant phase in the mix, although other nanophase Fe minerals may have been present. As the identification method is geared to comparison after continuum removal of absorption features, spectra with extremely weak features were taken to represent unidentifiable Fe minerals or poorly crystallized $\mathrm{Fe}$ substances if no match was found. Identification of 
poorly crystallized nanocrystalline (grain size $<9 \mu \mathrm{m}$ ) $\mathrm{Fe}^{3+}$ minerals, which may be common as pigmentary agents in rocks in the waste piles, is difficult because of the lack of knowledge of their spectral features in natural mixtures, such as those containing well-crystal-
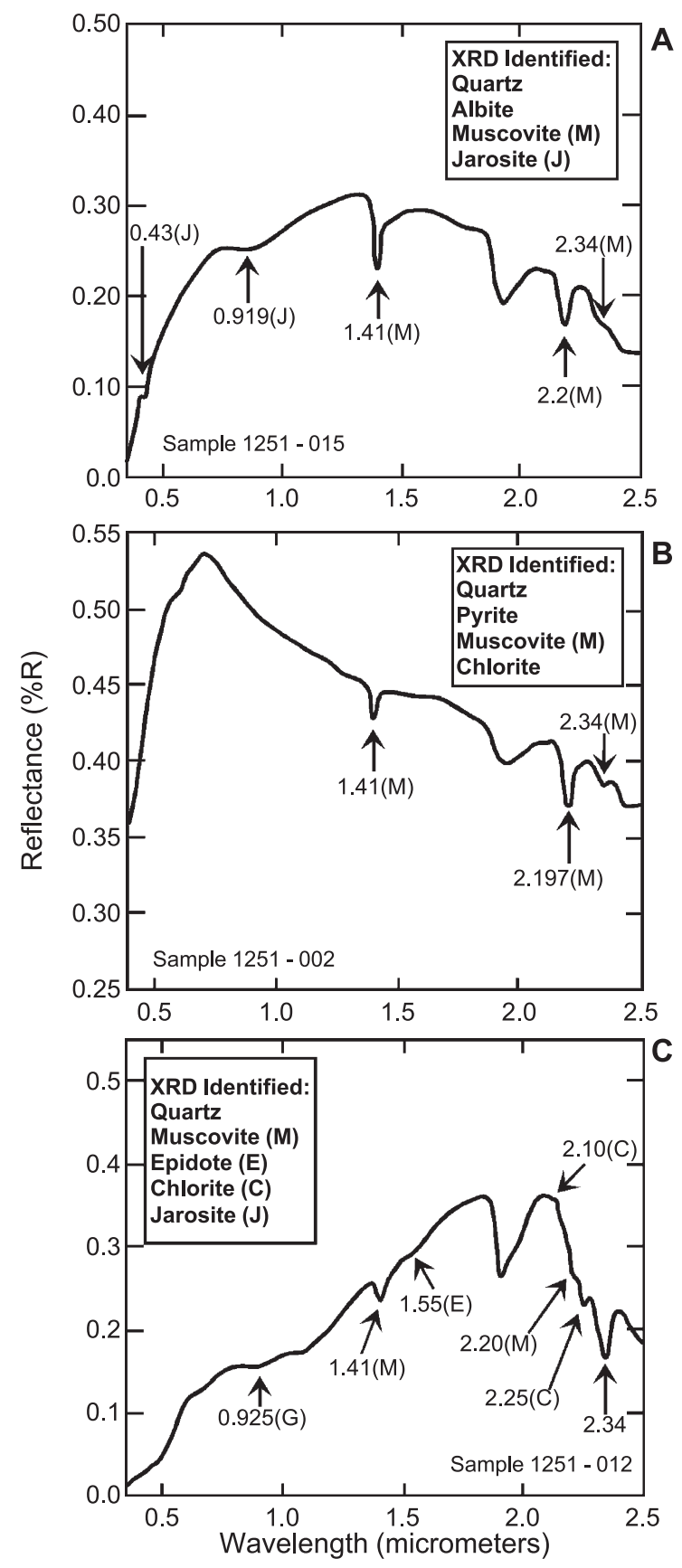

lized Fe minerals (Morris et al., 1993; Bishop et al., 1998). Sulfides, the ultimate target of most aciddrainage remediation, generally can be readily identified in the field through visual examination. Sulfides have very low reflectance and cannot be easily identified in reflectance spectra except where well exposed and in high concentration (Swayze et al., 2000).

Identification of sheet silicates, Fe silicates, carbonates and non-Fe sulfates was conducted in the region from 1.9 to $2.4 \mu \mathrm{m}$ by analysis of absorption features after continuum removal. Minerals containing $\mathrm{Fe}-$ $\mathrm{Mg}-\mathrm{OH}$, such as chlorite and epidote, which show very similar absorption features, can be distinguished by slight shape differences in the $2.3-\mu \mathrm{m}$ feature. If both chlorite and epidote were present, the spectra of rock samples after continuum removal consistently showed multiple bands and shoulders between 2.25 and $2.3 \mu \mathrm{m}$, plus narrow bands at $2.1 \mu \mathrm{m}$, attributable to $\mathrm{OH}$ in chlorite, and a band at $1.54 \mu \mathrm{m}$ attributable to $\mathrm{OH}$ in epidote (Fig. 6C). Sheet silicates containing $\mathrm{Al}-\mathrm{OH}$ were identified by band-shape analysis of the region between 2.2 and $2.34 \mu \mathrm{m}$. Rock samples containing muscovite yielded reflectance spectra with narrow features at approximately 2.2 and $2.34 \mu \mathrm{m}$. Narrow shoulderless features at $2.2 \mu \mathrm{m}$ are characteristic of muscovite. Kaolinite was identified on the basis of the characteristic double-absorption feature in the $2.16-2.2-\mu \mathrm{m}$ region (Fig. 5B). Slight symmetry differences in the $2.2-\mu \mathrm{m}$ absorption feature attributed to muscovite indicated slightly different spectral behavior of the Al-OH bond in muscovite mapped as "muscovite 1" and "muscovite 2" in Fig. 7. Analysis of laboratory reflectance spectra of wellcharacterized rock samples and their corresponding field reflectance spectra served as a guide for the interpretation of field reflectance spectra and the application of the apparent continuum removal and band-shape least-squares algorithm.

Fig. 6. Laboratory reflectance spectra of selected rock specimens collected at the Penn Mine site. The inserts list the minerals identified by XRD, with each accompanied by the letter used to identify its corresponding signature feature in the spectra. Arrows indicate spectral absorption features used to identify minerals from the laboratory spectra and the centers of those features after a continuum has been removed. (A) Oxidized muscovite-quartz schist. (B) Unoxidized pyritic muscovite-quartz schist. (C) Greenstone; $\mathrm{G}=$ goethite. 


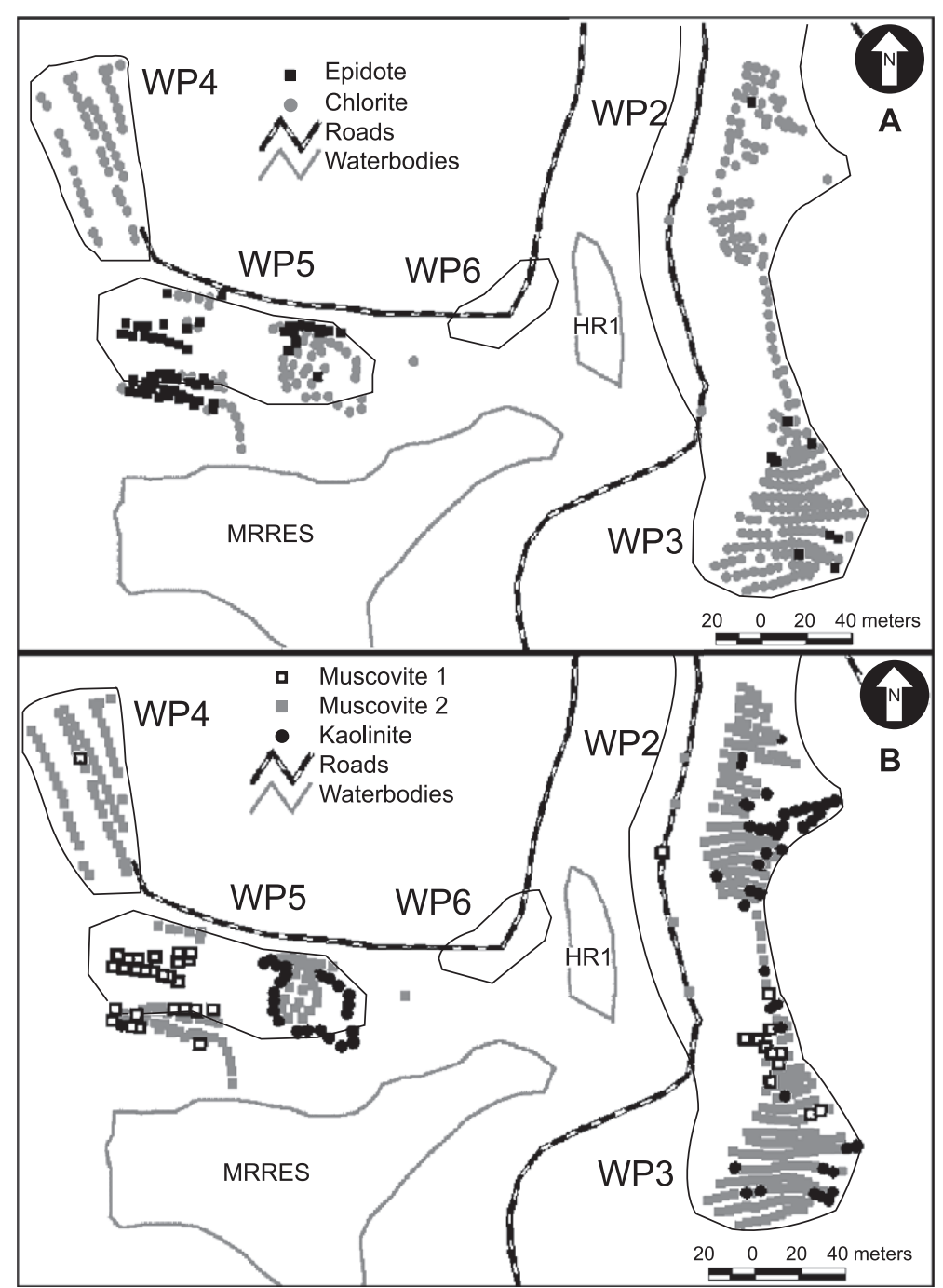

Fig. 7. Distribution of minerals on mining waste piles at the Penn Mine site as derived from reflectance spectra acquired over discrete localities. WP1 through WP6 are waste piles 1 through 6 (no spectra were acquired over WP6). HR1: Hinckley Run pond 1; MRRES: Mine Run reservoir. (A) Distribution of epidote and chlorite. (B) Distribution of muscovite and kaolinite.

\subsection{Mineral zones discerned and environmental implications}

Interpretation of the field spectra was used to create the mineral maps depicted in Figs. 7 and 8. These maps identified at least one area of low potential AMD generation, in a wide area of disturbed greenstone bedrock. Greenstones at the Penn Mine are sulfide-poor and do not present a high risk of AMD generation. Areas were mapped as greenstone if the field spectra showed the presence of epidote and chlorite, the former of which occurred only in unmineralized greenstone, whereas the latter is present in both greenstone and in mineralized mine waste.

Among the $\mathrm{Al}$ phyllosilicates, muscovite and kaolinite were predominant in the waste-rock piles. Reactions of muscovite with acidic solutions produced by sulfide oxidation can result in the production of kaolinite and other clay minerals and in the release of $\mathrm{K}$ necessary for jarosite precipitation (Ritchie, 1994); detectable areas of 


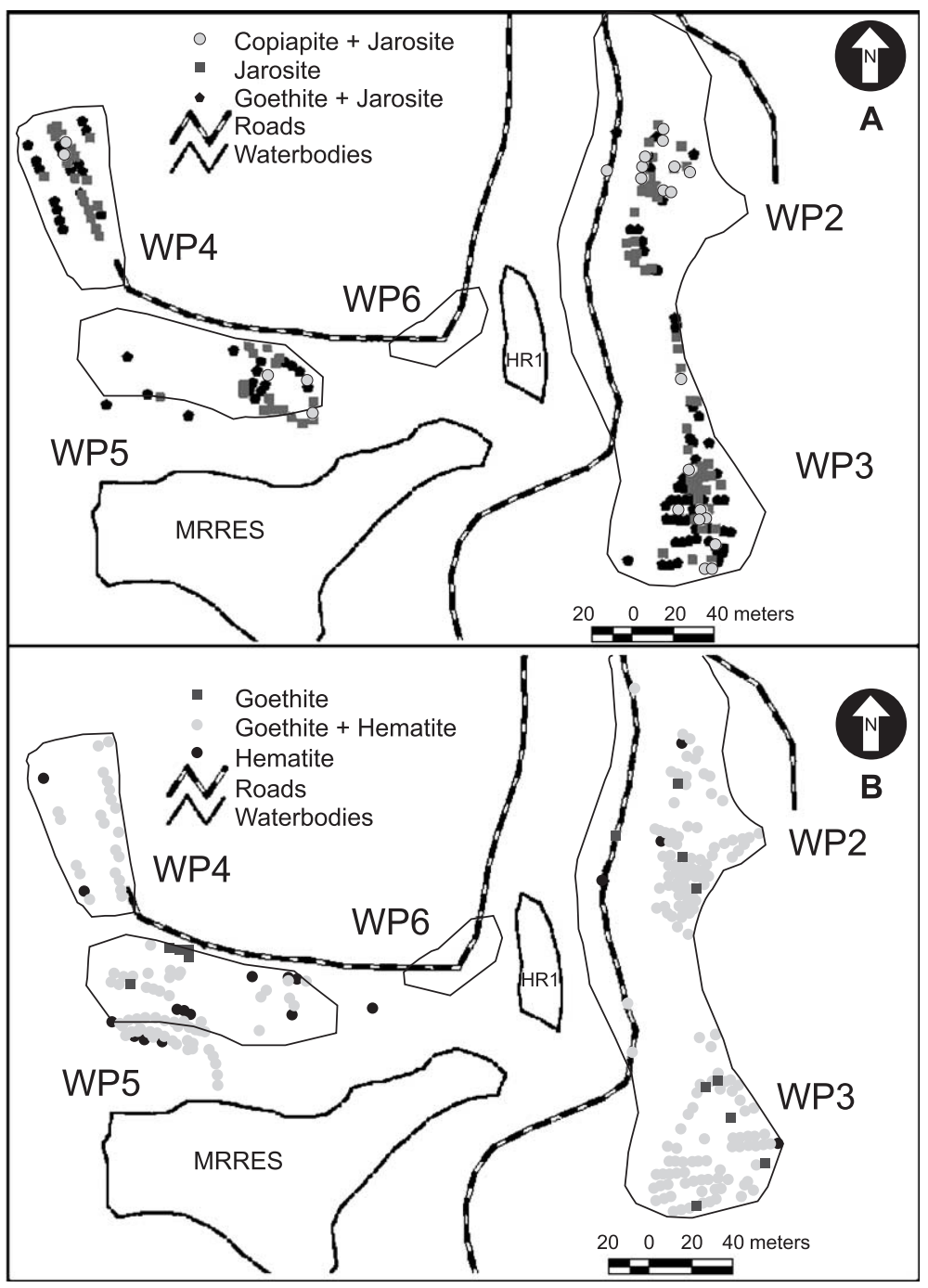

Fig. 8. Distribution of secondary Fe minerals at the Penn Mine. Sites are labeled as in Fig. 7 (no spectra were acquired over WP6). (A) Distribution of copiapite and jarosite, plus mixtures of jarosite and goethite, indicative of low-pH environments. (B) Distribution of goethite and hematite, indicative of higher $\mathrm{pH}$ environments.

kaolinite were expected where sulfide oxidation was thought to be intense enough to produce significant muscovite dissolution, but such areas were not detected. Kaolinite was mapped in waste pile 2 and in the southeastern corner of waste pile 3, in areas known to have a thin soil cover and wherein kaolinite might have been the product of weathering of rock unrelated to AMD (Fig. 7B). Other kaolinite areas in waste piles 5,2 and 3 might have been related either to muscovite weathering or to hydro- thermal alteration such as reported by Peterson (1985).

Fig. 8A and B indicate the four types of secondary Fe minerals mapped at the Penn Mine. Iron sulfates such as copiapite and jarosite that typically accumulate in low-pH environments ( $\mathrm{pH} 0.8-3.5$; Nordstrom et al., 1978) formed by rapid erosion and oxidation of sulfides, as well as evaporation of ponded AMD, near the center and topographically higher areas of the waste-rock piles. Surrounding the copiapite-jarosite 
centers are jarosite and mixtures of jarosite+goethite, which suggest higher $\mathrm{pH}$ areas where pore and surface water was less acidified by the AMD process. Pure goethite was mapped around jarosite, in areas typically near the outer limit of the area surveyed, indicating even higher $\mathrm{pH}$ farther away from oxidation centers. Rare occurrences of higher $\mathrm{pH}$ minerals near low-pH ones are attributed to irregular microtopography on the waste piles, which promoted fast erosion of material in higher areas and the ponding of surface waters at lower elevations. Given the irregular surface on top of waste piles at the time of the survey, the distribution of these minerals could have been better resolved using a sampling interval smaller than $5 \mathrm{~m}$.

In terms of AMD generation, the accumulation of copiapite and jarosite point to more acidic conditions than elsewhere on the dump surface, and indicate the source areas of AMD. The occurrence of low-pH minerals indicates a relatively immature waste-rock pile that had a high potential for AMD release. The accumulation of copiapite 2 weeks after a series of storms suggests that an even larger and more significant buildup of soluble $\mathrm{Fe}$ sulfates likely occurred at the end of each dry season. Given the solubility of minerals such as copiapite, the contribution of metals and sulfate to Camanche Reservoir from soluble sulfate salts was not insignificant. The occurrence of copiapite in high and unsheltered areas of the waste-rock piles, rather that in places sheltered from the rain, leads the authors to believe that copiapite observed during this study precipitated from evaporating water during the 2-week dry period.

Goethite accumulation is distal to the active oxidation centers, indicating an increase in the $\mathrm{pH}$ of the aqueous effluents as they move away from the unsaturated waste piles (Swayze et al., 2000). Hematite is abundant only where the lithology is dominated by greenstones, in areas with iron and steel infrastructure waste, and in areas near non-acidic standing water.

\section{Applicability of method}

Use of digital mapping methods at the Penn Mine site has the advantages of mapping efficiency and adaptability, which are crucial factors if the large number of abandoned mines still to be characterized is considered. During the survey, all information was available to the mapping team immediately. Thus, the survey could be modified quickly, control points could be added or discontinued as needed, and informed decisions could be made about how best to use the limited time, as storms threatened to shorten the field work period.

By using a field spectrometer close to the target area on the ground, we believe noise introduced by atmospheric water is minimized in comparison to high-altitude remote-sensing platforms. Over most areas at sea level, water molecules strongly absorb light at about 1.4 and $1.9 \mu \mathrm{m}$, with other minor regions of interference at $0.69,0.76,0.94$ and 1.13 $\mu \mathrm{m}$ (Vane et al., 1993). During the survey of the Penn Mine, light in the $1.4-\mu \mathrm{m}$ region was not completely absorbed by atmospheric water, and interference at $0.9 \mu \mathrm{m}$ and other regions was minimal because of the low humidity conditions, the short distance between the target and probe, and frequent optimization of the instrument with a white reflectance standard. Reduced water-related noise in ground-based reflectance spectroscopy provides a definite advantage over high-altitude remote-sensing platforms, for which data processing and noise reduction involve the use of probabilistic models that have little to do with actual atmospheric conditions on the day of data acquisition.

The use of a non-contact reflectance spectrometer facilitated the acquisition of reflectance spectra of the inaccessible steep sides of waste piles by allowing mineral identification of surfaces at a distance from the instrument. The use of a non-contact spectrometer also facilitated the future use of the ground-based data for ground-truthing of high-altitude hyperspectral data; the combination of airborne (or high altitude) with detailed ground-based hyperspectral data is commonly the optimal route for highly detailed characterization of complex environments such as abandoned mines.

Information in mineral maps (Figs. 7 and 8) that describe the surface weathering and acid-producing conditions at each waste pile are useful not only to those interested in the mineralogy of AMD environments, but also to governmental or private agencies in charge of remediating (or preventing) environmentally problematic sites. Swayze et al. (2000) showed the 
cost-effectiveness of obtaining hyperspectral remotesensing data over the California Gulch Superfund site at Leadville, $\mathrm{CO}$, as a guide to remediation efforts. Mineral maps such as Fig. 8A can also be useful to estimate the impact of the dissolution of soluble $\mathrm{Fe}$ sulfates to surface water bodies or stormwater management and treatment systems.

Mapping of mineral zones at the Penn Mine based on interpolation between survey points revealed an area of $1070 \mathrm{~m}^{2}$ on the waste-rock piles that was overlain by a mixture of jarosite and copiapite. Using conservative assumptions that the Fe-sulfate minerals occur within the top $0.1 \mathrm{~cm}$ yields a $\mathrm{Fe}$ sulfate volume of $1070 \mathrm{~cm}^{3}$. If copiapite, of density $2.1 \mathrm{~g}$ $\mathrm{cm}^{-3}$ (Gaines et al., 1997), constituted as little as $10 \%$ of this volume, an estimated mass of $2247 \mathrm{~g}$ of copiapite existed on the surface of the waste-rock piles. Dissolution by rain of those $2247 \mathrm{~g}$ of copiapite would result in a sudden release of approximately $1035 \mathrm{~g}$ of sulfate to surface water in addition to that contributed by other sources. Similar calculations can be carried out for metals present in the structure of $\mathrm{Fe}$ sulfates such as copiapite $(\mathrm{Fe}, \mathrm{Cu}$, $\mathrm{Zn}, \mathrm{Pb}, \mathrm{Al}, \mathrm{Mn}, \mathrm{Mg}$ and $\mathrm{K}$ ) in order to estimate the mass of metals to surface water after dissolution. Use of mineral maps constructed from data acquired before the start of the rain season could anticipate and potentially help prevent bigger releases of sulfate and metals.

\section{Conclusions}

The use of an integrated digital mapping system proved to be an efficient way to map mine wastes accurately and in detail at the relatively small, abandoned Penn Mine. Most of the surface oxidation and acid-production activity was focused in waste piles 2, 3, 4 and the eastern part of pile 5, whereas the western part of waste pile 6 had mostly unmineralized greenstones and secondary minerals that precipitated at a higher $\mathrm{pH}$. Observations of this type enable the translation of the mineral maps into remediation-priority maps, in which the piles that host high concentrations of low-pH minerals are interpreted to have the most potential to release AMD and thus could be scheduled for removal at an optimal stage of the remediation. Mineral maps showing the distribution of soluble metal-bearing sulfate salts are also useful in the design and placement of stormwater diversions, berms and neutralization basins.

Results such as those derived in this study can be can be used to aid both the interpretation and the ground-truthing of remote-sensing data, thereby enlarging the area that can be mapped and increasing the accuracy of delineation of known and unidentified AMD-generating sites. The advantages of using a digital, portable mapping system in combination with a portable spectrometer with DGPS and supporting laser rangefinder were evident in light of the constrained working environment in which time was the scarcest resource. Maps derived from the low-altitude, low-atmospheric-noise, and closely sampled spectra yielded abundant information regarding the distribution of AMD-related minerals on the surface of wasterock piles at the Penn Mine. The mineral maps offer a detailed and complete view of the mineral distribution on the surface of the waste-rock piles and surrounding areas, thus offering a mine-wide view of the processes at play in the generation of AMD.

\section{Acknowledgments}

This research was supported by NASA RESAC, NASA Mission to Planet Earth grant NAG5-6515 entitled "Center for Assessment and Monitoring of Forest and Environmental Resources (CAMFER) and the Earth Resources Center (ERC)", by Earth Resources Center funds from the UC Berkeley Office of the Vice Chancellor for Research, and by the Charles J. Meyer Memorial Fellowship. The authors thank Peggy Gennaro (UC-Berkeley Mineralogical Museum), Jeffrey Post (Mineral Museum of the Smithsonian Institution) and Heather Jamieson (Queen's University) for their help in finding appropriate mineral samples for our spectral library. Gratitude is also owed to the East Bay Municipal Utility District for access to the Penn Mine site, and to J. Bishop, A. Thompson, B. Seal and J.L. Jambor for careful and insightful reviews that improved this paper. Use of trade, product or firm names in this publication is for descriptive purposes only and does not imply endorsement by the U.S. government. [PD] 


\section{References}

Adams, J.B., Filice, A.L., 1967. Spectral reflectance 0.4 to 2.0 microns of silicate rock powders. J. Geophys. Res. 72, $5705-5715$.

Alpers, C.N., Blowes, D.W., Nordstrom, D.K, Jambor, J.L., 1994a. Secondary minerals and acid mine-water chemistry. In: Jambor, J.L., Blowes, D.W. (Eds.), Environmental Geochemistry of Sulfide Mine-Wastes, Mineral. Assoc. Can. Short Course, vol. 22, pp. 247-270.

Alpers, C.N., Hamlin, S.N., Rye, R.O., 1994b. Stable isotopes (O, H, S) distinguish sources of acid drainage at Penn Mine, California. U.S. Geol. Surv. Circ. 1107, 4.

Alpers, C.N., Hamlin, S.N., Hunerlach, M.P., 1999. Hydrogeology and geochemistry of acid mine drainage in ground water in the vicinity of Penn Mine and Camanche Reservoir, Calaveras County, California: summary report: 1993-1995. U.S. Geol. Surv. Water-Resour. Investig. Rep., 96-4287.

Analytical Spectral Devices, 1999. In: Hatchell, D. (Ed.), Technical Guide, (3rd ed.), Analytical Spectral Devices, Boulder, Colorado.

Bigham, J.M., 1994. Mineralogy of ochre deposits formed by sulfide oxidation. In: Jambor, J.L., Blowes, D.W. (Eds.), Environmental Geochemistry of Sulfide Mine-Wastes, Mineral. Assoc. Can. Short Course, vol. 22, pp. 105-133.

Bigham, J.M., Schwertmann, U., Carlson, L., Murad, E., 1990. A poorly crystallized oxyhydroxysulfate of iron formed by bacterial oxidation of $\mathrm{Fe}(\mathrm{II})$ in acid mine waters. Geochim. Cosmochim. Acta 54, 2743-2758.

Bishop, J.L., Murad, E., 1996. Schwertmannite on Mars? Spectroscopic analysis of schwertmannite, its relation to other minerals, and its possible presence in the surface material on Mars. In: Dyar, M.D., McCammon, C., Schaefer, M.W. (Eds.), Mineral Spectroscopy: A Tribute to Roger G. Burns, Spec. Pub. Series. The Geochemical Society, Washington, DC, pp. 337-358.

Bishop, J.L., Pieters, C.M., Edwards, J.O., 1994. Infrared spectroscopy of the nature of water in montmorillonite. Clays Clay Miner. 42, 702-716.

Bishop, J.L., Fröschl, H., Mancinelli, R.L., 1998. Alteration processes in volcanic soils and identification of exobiologically important weathering products on Mars using remote sensing. J. Geophys. Res. 103, 31457-31476.

Brimhall, G., Vanegas, A., 2001. Removing science workflow barriers to adoption of digital geological mapping by using the Geomapper Universal Program and Visual User Interface. In: Soller, D.R. (Ed.), Digital Mapping Techniques '01 - Workshop Proceedings. U.S.G.S. Open File Rep. 01-223, 103-114<http:/ www.pubs.usgs.gov/of/2001/0f01-223>.

Burns, R.G., 1993. Origin of electronic spectra of minerals in the visible to near-infrared region. In: Pieters, C.M., Englert, P.A.J. (Eds.), Remote Geochemical Analysis: Elemental and Mineralogical Composition, vol. 4. Cambridge University Press, Cambridge, UK, pp. 3-29.

California Department of Conservation, 2000. California's abandoned mines, a report on the magnitude and scope of the issue in the State. Abandoned Mine Lands Unit, vol. 1. Dep. Conservation, Sacramento, California.
Clark, R.N., 1999. Spectroscopy of rocks and minerals and principles of spectroscopy. In: Rencz, A.N. (Ed.), Manual of Remote Sensing, Remote Sensing for the Earth Sciences, vol. 3. Wiley, New York, pp. 3-58.

Clark, R.N., Roush, T.L., 1984. Reflectance spectroscopy: quantitative analysis techniques for remote sensing applications. J. Geophys. Res. 89, 6329-6340.

Clark, R.N., Gallagher, A., Swayze, G.A., 1990a. Material absorption band depth mapping of imaging spectrometer data using a complete band shape least-squares fit with library reference spectra. Proceed. 2nd AVIRIS Earth Sci. Workshop, JPL, vols. 90-54, pp. 176-186.

Clark, R.N., Swayze, G.A., King, T.V.V., Middlebrook, B., Calvin, W.M., Gorelick, N., 1990b. The U.S. Geological Survey digital spectral library and analysis software. Proceed. 2nd AVIRIS Earth Sci.Workshop, JPL, vols. 90-54, pp. 208-215.

Clark, R.N., King, T.V., Klewja, M., Swayze, G.A., 1990c. High spectral resolution reflectance spectroscopy of minerals. J. Geophys. Res. 95, 12653-12680.

Clark, W.B., Lydon, P.A., 1962. Mines and Mineral Resources of Calaveras County, California. County Report 2. California Div. Mines Geol, San Francisco.

Dalton, J.B., King, T.V.V., Bove, D.J., Kokaly, R.F., Clark, R.N., Swayze, G.A., 1998. Mapping of acid-generating and acidbuffering minerals in the Animas watershed by AVIRIS spectroscopy. Proc. 7th AVIRIS Earth Sci. Workshop, JPL, vols. 97-21, 4 pp.

Davy Environmental, 1993. Site characterization report, Penn Mine, Calaveras County, California. Prepared for California Regional Water Quality Control Board, Central Valley Region.

Fanfani, L., Nunzi, A., Zanazzi, P.F., Zanzari, A.R., 1973. The copiapite problem: the crystal structure of a ferrian copiapite. Am. Mineral. 58, 314-322.

Ferrier, G., 1999. Application of imaging spectrometer data in identifying environmental pollution caused by mining at Rodalquilar, Spain. Remote Sens. Environ. 68, 125-137.

Gaffey, S.J., McFadden, L.A., Nash, D., Pieters, C., 1993. Ultraviolet, visible, and near-infrared reflectance spectroscopy: laboratory spectra of geologic materials. In: Pieters, C., Englert, P. (Eds.), Remote Geochemical Analysis: Elemental and Mineralogical Composition. Cambridge University Press, New York, pp. 43-77.

Gaines, R.V., Skinner, H.C., Foord, E.E., Mason, B., Rosenzweig, A., 1997. Dana's New Mineralogy. Wiley, New York.

Hamlin, S.N., Alpers, C.N., 1995. Hydrogeology and geochemistry of acid mine drainage in ground water in the vicinity of Penn Mine and Camanche Reservoir, Calaveras County, California: first-year summary, 1992-93. U.S. Geol. Surv. Water-Resour. Investig. Rep., 94-4040.

Hamlin, S.N., Alpers, C.N., 1996. Hydrogeology and geochemistry of acid mine drainage in ground water in the vicinity of Penn Mine and Camanche Reservoir, Calaveras County, California: second-year summary, 1992-93. U.S. Geol. Surv. Water-Resour. Investig. Rep., 96-4257.

Hauff, P.L., Peters, D.C., Borstad, G., Peppin, W., Dillenbeck, E., Cross, L.G., Prosh, E.C., 2000. Hyperspectral investigations of mine waste and abandoned mine lands - the Dragon calibration 
site study. Proceed. 10th AVIRIS Earth Sci. Workshop. Pasadena, JPL, 9 pp.

Heyl, G., 1944. Quail Hill Mine, Foothill copper-zinc belt, Calaveras County, CA. U.S. Geol. Surv. Strateg. Miner. Investig. Prelim., 3-182.

Hunt, G.R., 1979. Near-infrared (1.3-2.4 $\mu \mathrm{m})$ spectra of alteration minerals - potential for use in remote sensing. Geophysics 44 , 1974-1986.

Hunt, G.R., Salisbury, J., Lenhoff, C., 1971. Visible and nearinfrared spectra of minerals and rocks: III. Oxides and hydroxides. Mod. Geol. 2, 195-205.

Hunt, G.R., Salisbury, J., Lenhoff, C., 1973. Visible and nearinfrared spectra of minerals and rocks: VI. Additional silicates. Mod. Geol. 4, 85-106.

Jambor, J.L., Nordstrom, D.K., Alpers, C.N., 2000. Metal-sulfate salts from sulfide mineral oxidation. In: Alpers, C.N., Jambor, J.L., Nordstrom, D.K. (Eds.), Sulfate Minerals-Crystallography, Geochemistry, and Environmental Significance, Rev. Mineral. Geochem., vol. 40, pp. 305-350.

King, T.V.V., Clark, R.N., 1989. Spectral characteristics of chlorites and $\mathrm{Mg}$-serpentines using high resolution reflectance spectroscopy. J. Geophys. Res. 94, 13997-14008.

Klein, C., Hurlbut, C.S., 1993. Manual of Mineralogy. Wiley, New York.

Kruse, F.R., Dwyer, J.L., 1995. The effects of AVIRIS atmospheric calibration methodology on identification and quantitative mapping of surface mineralogy, Drum Mtns. Utah. Proceed. 5th AVIRIS Earth Sci. Workshop, JPL vols. 95-1, pp. 101-104.

Laser Atlanta, 2000. Advantage ${ }^{\circledR}$ User Guide. <http://www. laseratlanta.com>.

Martin, R.C., 1988. Volcanogenic massive sulfide belt of the Western Sierra Nevada foothills. Calif. Geol. 41, 195-204.

Morris, R., Lauer, H., Lawson, C., Gibson Jr., E., Nace, G., Stewart, C., 1985. Spectral and other physicochemical properties of submicron powders of hematite $\left(\alpha-\mathrm{Fe}_{2} \mathrm{O}_{3}\right)$, maghemite $(\gamma$ $\left.\mathrm{Fe}_{2} \mathrm{O}_{3}\right)$, magnetite $\left(\mathrm{Fe}_{3} \mathrm{O}_{4}\right)$, goethite $(\alpha-\mathrm{FeOOH})$, and lepidocrocite $(\gamma$-FeOOH). J. Geophys. Res. 90, 3126-3144.

Morris, R., Golden, D., Bell III, J., Lauer, H.V., Adams, J.B., 1993. Pigmenting agents in Martian soils: inferences from spectral, Mössbauer, and magnetic properties of nanophase and other iron oxides in Hawaiian palagonitic soil PN-9. Geochim. Cosmochim. Acta 57, 4609-4795.

Morris, R., Ming, D., Golden, D., Bell III, J., 1996. An occurrence of jarositic tephra on Mauna Kea, Hawaii: implications for the ferric mineralogy of the Martian surface. In: Dyar, M.C., McCammon, C., Schaefer, M.W. (Eds.), Mineral Spectroscopy: A Tribute to Roger G. Burns, Spec. Pub. Series, vol. 5. The Geochemical Society, Washington, DC, pp. 327-336.

Murray, J.W., 1979. Iron oxides. In: Burns, R.G. (Ed.), Marine Minerals, Rev. Mineral., vol. 6. , pp. 47-98.

Nordstrom, D.K., Alpers, C.N., 1999a. Geochemistry of acid mine waters. In: Plumlee, G.S., Logsdon, M.J. (Eds.), The Environmental Geochemistry of Mineral Deposits: Part A. Processes, Techniques, and Health Issues, Rev. Econ. Geol., vol. 6A, pp. $133-155$.

Nordstrom, D.K., Alpers, C.N., 1999b. Negative pH, efflorescent mineralogy, and consequences for environmental restoration at the Iron Mountain Superfund site, California. Proc. Natl. Acad. Sci. U. S. A. 96, 3455-3462.

Nordstrom, D.K., Dagenhart, T.V., 1978. Hydrated iron sulfate minerals associated with pyrite oxidation: field relations and thermodynamic properties. Geol. Soc. Am. Abstr. Programs 10, 464.

Nordstrom, D.K., Jenne, E.A., Ball, J.W., 1978. Redox equilibria of iron in acid mine waters. In: Jenne, E.A. (Ed.), Chemical Modeling in Aqueous Systems: Speciation, Sorption, Solubility, and Kinetics, Am. Chem. Soc. Symp. Ser., vol. 93, pp. $51-79$.

Peterson, J., 1985. Geologic map of the Penn Mine, Calaveras County, California. U.S. Geol. Surv. Misc. Stud. Map MF-1797.

Peterson, J., 1988. Distribution of selected trace and major elements around the massive sulfide deposit at the Penn Mine, California. Econ. Geol. 83, 419-427.

Plumlee, G.S., Smith, K., Montour, M., Ficklin, W., Mosier, M., 1999. Geologic controls on the composition of natural waters and mine waters draining diverse mineral deposit types. In: Filipek, L.H., Plumlee, G.S. (Eds.), Environmental Geochemistry of Mineral Deposits: Part B. Case Studies and Research Topics, Rev. Econ. Geol., vol. 6B, pp. 373-432.

Ritchie, A.I.M., 1994. The waste-rock environment. In: Jambor, J.L., Blowes, D.W. (Eds.), Environmental Geochemistry of Sulfide Mine-Wastes, Mineral. Assoc. Can. Short Course, vol. 22, pp. $133-161$.

Rossman, G.R., 1975. Spectroscopic and magnetic studies of ferric iron hydroxy sulfates: intensification of color in ferric iron clusters bridged by a single hydroxide ion. Am. Mineral. 60, $698-704$.

Rossman, G.R., 1976. Spectroscopic and magnetic studies of ferric ion hydroxy sulfates: the series $\mathrm{Fe}(\mathrm{OH}) \mathrm{SO}_{4} \cdot n \mathrm{H}_{2} \mathrm{O}$ and the jarosites. Am. Mineral. 61, 398-404.

Rossman, G.R., 1996. Why hematite is red: correlation of optical absorption intensities and magnetic moments of $\mathrm{Fe}^{3+}$ minerals. In: Dyar, M.D., McCammon, C., Schaefer, M.W. (Eds.), Mineral Spectroscopy: A Tribute to Roger G. Burns, Spec. Pub. Series, vol. 5. The Geochemical Society, Washington, DC, pp. 23-27.

Sherman, D.M., Waite, T.D., 1985. Electronic spectra of $\mathrm{Fe}^{3+}$ oxides and oxyhydroxides in the near infrared to ultraviolet. Am. Mineral. 70, $1262-1269$.

Sherman, D.M., Burns, R.G., Burns, V.M., 1982. Spectral characteristics of the iron oxides with applications to the Martian Bright Region mineralogy. J. Geophys. Res. 87, 10169-10180.

Singer, D.A., 1986. Descriptive model of Kuroko massive sulfide. In: Cox, D.P., Singer, D.A. (Eds.), Mineral Deposit Models, U.S. Geol. Surv. Bull., vol. 1693, pp. 189-197.

Singer, D.A., 1992. Grade and tonnage model of Sierran Kuroko deposits. In: Bliss, J.D. (Ed.), Developments in Mineral Deposit Modeling, U.S. Geol. Surv. Bull., 2004, pp. 29-33.

Swayze, G.A., Smith, K.S., Clark, R.N., Sutley, S.J., Pearson, R.M., Vance, J.S., Hugeman, P.L, Briggs, P.H., Meier, A.L., Singleton, M.J., Roth, S., 2000. Using imaging spectroscopy to map acidic mine waste. Environ. Sci. Technol. 34, 47-54.

Takagi, T., Brimhall, G., 2001. An integrated approach to screening of abandoned mines for remediation: digital field mapping, IR spectrometry, and time-series water chemistry. 
IAMG 2001 Proceedings. Internat. Assoc. Math. Geol. Ann. Conf., CD-ROM.

Townsend, T.E., 1987. Discrimination of iron alteration minerals in visible and near-infrared reflectance data. J. Geophys. Res. 92, $1441-1454$.
Vane, G., Duval, J.E., Wellman, J.B., 1993. Imaging spectroscopy of the Earth and other solar system bodies. In: Pieters, C., Englert, P. (Eds.), Remote Geochemical Analysis: Elemental and Mineralogical Composition. Cambridge University Press, New York, pp. 121-166. 